\title{
Boron Sources and Levels on the Nutrition and Production of Common Bean Intercropped With Castor
}

\author{
Mateus Leles Lima ${ }^{1}$, Gisele Carneiro Silva ${ }^{2}$, Isneider Luiz Silva ${ }^{1}$, Cristiane Fernandes Lisboa ${ }^{1}$, \\ Deyner Damas Aguiar Silva ${ }^{1}$, Edgar Estevam França ${ }^{1}$, Itamar Rosa Teixeira ${ }^{1} \&$ Adilson Pelá ${ }^{3}$ \\ ${ }^{1}$ Universidade Estadual de Goiás, Campus CCET, Anápolis, Goiás, Brazil \\ ${ }^{2}$ Universidade Estadual de Goiás, Campus Posse, Posse, Goiás, Brazil \\ ${ }^{3}$ Universidade Estadual de Goiás, Campus Ipameri, Goiás, Brazil \\ Correspondence: Itamar Rosa Teixeira, Universidade Estadual de Goiás, Campus CET, BR 153, Fazenda \\ Barreiro do Meio, Brazil. Tel: 55-623-328-1156. E-mail: itamar.texeira@ueg.br
}

Received: February 7, 2018

Accepted: May 2, $2018 \quad$ Online Published: June 15, 2018

doi:10.5539/jas.v10n7p218

URL: https://doi.org/10.5539/jas.v10n7p218

The research is financed by Conselho Nacional de Desenvolvimento Cientifico e Tecnológico (CNPq).

\begin{abstract}
This study was to evaluate the nutrition and the agronomic part of bean intercropped with castor crops submitted to sources and levels of B in the Anápolis-GO, Brazil. The treatments consisted of two sources of B (borax = $11 \% \mathrm{~B}$ and boric acid $=17 \% \mathrm{~B})$ combined with five levels of $\mathrm{B}\left(0.0,0.5,1.0,2.0\right.$ and $4.0 \mathrm{~kg} \mathrm{ha}^{-1}$ in soil) in bean intercropped with castor, plus monoculture, using $1.0 \mathrm{~kg} \mathrm{ha}^{-1} \mathrm{~B}$. That leaf levels of $\mathrm{B}$ and $\mathrm{S}$ in beans, and of $\mathrm{B}, \mathrm{N}$, $\mathrm{Ca}, \mathrm{Mg}$ and $\mathrm{Fe}$ in castor were influenced by the sources and levels of $\mathrm{B}$ in the intercropping. The bean yield intercropped with castor was not influenced by borated fertilization, neither by the interaction of factors. The highest yield of castor intercropped with beans, $2.040 \mathrm{~kg}_{\text {of grains ha }}{ }^{-1}$, was obtained with the $1.9 \mathrm{~kg} \mathrm{ha}^{-1}$ of B, regardless of the source used.
\end{abstract}

Keywords: Phaseolus vulgaris L., Ricinus communis L., intercropping, micronutrient, nutrition, yield

\section{Introduction}

Intercropping is commonly used in tropical regions of the world, especially in small rural farms. However, the effective advantage of this technique compared to monoculture becomes more evident when the crops involved have different requirements in terms of available resources, whether in quality, quantity, or time of need (Teixeira et al., 2005). Thus, intercropping efficiency is dependent on the complementarity between the crops involved, the available management practices, and the environmental conditions (Lithourgidis et al., 2011).

The cultivation of castor (Ricinus communis L.), indicated by the federal government of Brazil as the first choice for biodiesel production-related projects, used mainly intercropped with short cycle crops such as common bean (Phaseolus vulgaris L.) (Teixeira et al., 2012, 2011), the main protein source for lower income classes, may constitute a good option for farmers. Moreover, the adoption of the system will allow family farmers to deal with the drought in between cropping seasons in areas with well-defined climatic periods, as well as in the areas of "cerrado", providing extra earnings and therefore improving their life quality.

Castor plants, in turn, are reported to have been used very successfully intercropped with short cycle annual crops (Corrêa et al., 2006; Beltrão et al., 2010a, 2010b; Devide et al., 2010; Pereira et al., 2015; Alvarez et al., 2015; Dutra et al., 2017; Furtado et al., 2017), due to easy management and investment pay-off through seed selling, as well as to integration of crop remains and fertilizer residues into the soil. The common bean can represent a good alternative for intercropping with castor, not only for being important in Brazilian eating habits, but also for morphophysiological adaptation to the system as a $\mathrm{C} 3$ plant (Vieira, 2006) and as a fabaceae (legume), which is capable of restoring nitrogen to the soil.

In the case of castor used in intercropping with common beans, literature information refers only to the Vigna unguiculata species, whose assigned names are: kid beans, string beans, picker beans, among others. However, 
these are known to have highly aggressive growth as they are creeping plants (type IV), which may seriously endanger the castor yield, as demonstrated by Corrêa et al. (2006) and Oliveira Filho et al. (2016).

Studies on fertilization in castor crops were resumed recently in tropical conditions (Oliveira et al., 2010; Moro et al., 2011; Diniz Neto et al., 2012; Ferreira et al., 2014) due to the importance of the crop in the production of biofuel. However, they are still scarce and contemplate few genotypes commonly used by producers, besides being recommended mostly for the northeast region of Brazil (Lisboa et al., 2018).

In the Midwest of Brazil, where the castor crop is emerging there is no information on the subject yet. In some cases, recommendations of fertilization of single crops are widespread, with no real knowledge of the crop needs under the edaphoclimatic conditions prevailing in the region. Nevertheless, current studies addressing the castor nutrition theme are reportedly scarce and inconclusive, especially those related to the supply of micronutrients like boron, regarding the sources and levels to be used in fertilization. In turn, the common bean plant monoculture is said to have become highly profitable with the use of high technology in the activity, which has led to productivity levels above 3,500 kg ha ${ }^{-1}$ in Midwestern States such as Goiás and the Federal District, Brazil. However, for the intercropping system mineral nutrition studies are rare, especially addressing the use of boron sources and rates.

Satisfactory crop yields involved in intercropping will only be achieved with knowledge of the actual nutritional requirements of castor and common bean plants under this system. Therefore, studies should be carried out in order to evaluate the response of intercropped castor and common bean plants to borated fertilization and its influence on nutrition and production, and provide relevant information to technicians and producers.

Given the scarcity of information on the nutritional requirements of intercropped common and castor, this study was aimed at evaluating the effect of two sources and five levels of boron on the nutrition and production of intercropped common and castor under the climatic conditions of Goiás State central region, Brazil.

\section{Material and Methods}

\subsection{General Information}

The experiment was carried out during the 2010/2011 rainy-season crop at Emater Experimental Station in Anápolis, GO (Former Rural Agency), Brazil. The area geographical coordinates are $17^{\circ} 43^{\prime} 19^{\prime \prime} \mathrm{S}, 48^{\circ} 09^{\prime} 35^{\prime \prime} \mathrm{W}$ and $820-\mathrm{m}$ altitude. The region's climate is classified as Cwa-Mesothermal Humid, with rainfall of 1,750 mm and average annual temperature of $25^{\circ} \mathrm{C}$ (Seplan, 2012).

Soil samples classified as dystroferric Oxisol, an area previously cultivated with corn in the last three years, were collected and sent to the laboratory for chemical-physical analysis, and presented the following results: $\mathrm{pH}\left(\mathrm{H}_{2} \mathrm{O}\right)$ $=6.1 ; \mathrm{P}\left(\mathrm{mg} \mathrm{dm}^{-3}\right)=2.1 ; \mathrm{K}^{+}\left(\mathrm{cmol}_{\mathrm{c}} \mathrm{dm}^{-3}\right)=72 ; \mathrm{Ca}^{2+}\left(\mathrm{cmol}_{\mathrm{c}} \mathrm{dm}^{-3}\right)=4.5 ; \mathrm{Mg}^{2+}\left(\mathrm{cmol}_{\mathrm{c}} \mathrm{dm}^{-3}\right)=1.5 ; \mathrm{Al}^{3+}\left(\mathrm{cmolc}^{-3}\right.$ $\left.\mathrm{dm}^{-3}\right)=0.3 ; \mathrm{H}+\mathrm{Al}^{3+}\left(\mathrm{cmolc} \mathrm{dm}^{-3}\right)=5.5 ; \mathrm{m}(\%)=0.4 ; \mathrm{V}(\%)=61 ; \mathrm{B}\left(\mathrm{mg} \mathrm{dm}^{-3}\right)=0.3 ; \mathrm{Cu}\left(\mathrm{mg} \mathrm{dm}^{-3}\right)=1.8 ; \mathrm{Fe}$ $\left(\mathrm{mg} \mathrm{dm}{ }^{-3}\right)=175.0 ; \mathrm{Mn}\left(\mathrm{mg} \mathrm{dm}^{-3}\right)=16.5 ; \mathrm{Zn}\left(\mathrm{mg} \mathrm{dm}^{-3}\right)=3.7$; organic carbon $\left(\mathrm{g} \mathrm{kg}^{-1}\right)=23$; sand $\left(\mathrm{g} \mathrm{kg}^{-1}\right)=315$; silt $\left(\mathrm{g} \mathrm{kg}^{-1}\right)=153$ and clay $\left(\mathrm{g} \mathrm{kg}^{-1}\right)=532$.

\subsection{Experimental Design and Treatments}

A $2 \times 5+2$-factor randomized block design was used, with three replications. The treatments consisted of two sources of B (11\% borax and $17 \%$ boric acid) combined with five levels of B $\left(0.0,0.5,1.0,2.0\right.$ and $4.0 \mathrm{~kg} \mathrm{ha}^{-1}$ of soil) intercropped (+ castor), plus the additional monocultures of castor and common bean, each treated with a 1.0-kg-ha ${ }^{-1}$ boron sourced from boric acid. Such boron sources and levels were initially mixed with washed sand, which was the vehicle used due to the nutrient low dosages. The mixture was subsequently added to the soil together with the fertilizer prior to the sowing.

The intercropped castor plots consisted of four 5.0-m-long rows, spaced at $3.0 \mathrm{~m}$, and in between the rows four bean rows were planted, spaced at 0.5 meters. The plots of monoculture of castorwere composed of four 5 meters rows, spaced at 3.0 meters; common beans were planted in four 5 meters $(\mathrm{m})$ rows spaced at 0.5 meters. In both intercropped and monoculture plots, the two central lines were considered as working area.

\subsection{Plant Materials and Farming Practices}

The castor cultivar used was Paraguaçu, which has average size (1.6-m average height), stem covered with purple wax, semi-dehiscent fruits, large black seeds with high oil content (48\%). This cultivar was developed for cultivation in semiarid regions and use in family farming, with manual sowing and harvesting. It has great tolerance to drought and moderate susceptibility to gray mold (Embrapa, 2007).

As for common bean, the Pérola cultivar was used, which has commercial carioca grade grains, semi-erect standingand normal cycle (85-95 days). It is resistant to rust, common mosaic and to an anthracnose race. It also 
has intermediate resistance (the disease attacks, yet with no major production loss) to fusarium wilt and blight (Embrapa, 2004).

The soil was prepared in a conventional manner, with plowing and disking. The castor and common bean sowing was carried out simultaneously and manually within the row grooves on November 15, 2010. An additional $25 \%$ of seeds were sown, and $10 \mathrm{DAE}$ plant thinning was accomplished, in order to achieve castor and common bean density of 1 and 12 plants per linear meter, respectively. At 25 DAE, urea topdressing was done at a $40 \mathrm{~kg}-\mathrm{ha}^{-1}$ rate, in continuous bead along the planted rows of both castor and common beans.

After soil analyses, fertilization appropriate to the experimental station soil needs was accomplished in both crops, with the 05-25-15 formula at a level of $400 \mathrm{~kg} \mathrm{ha}^{-1}$. During the crop cycle,post-emergence weed control was carried outwith a hoe and chemically,with commercial mixtures of herbicides fomesafen+fluazifop-p-butyl, at a $1.0-\mathrm{L}-\mathrm{ha}^{-1}$ rate, at 20 and 30 days after crop emergence. Two applications of procymidone fungicide were done, at a $1.0-\mathrm{kg}^{-} \mathrm{ha}^{-1}$ rate, for gray mold control (Amphobotrys ricini) in the castor crop, and anthracnose (Colletotrichum lindemuthianum) and angular leaf spot (Phaeoisariopsis griseola) in common bean. Application of a $50-\mathrm{mL}-\mathrm{ha}^{-1}$ rate of deltamethrin insecticide was also accomplished to control leafhopper (Empoasca kraemeri).

\subsection{Evaluated Characteristics}

At full flowering of the crop involved in the study, 10 leaves and 20 trifoliate leaves of castor and common bean, respectively, were collected in the working area of each plot. Subsequently, the materials were analyzed for leaf $\mathrm{N}, \mathrm{P}, \mathrm{K}, \mathrm{Ca}, \mathrm{Mg}, \mathrm{B}, \mathrm{Cu}, \mathrm{Fe}, \mathrm{Mn}$ and $\mathrm{Zn}$ contents, according to the methodology described by Malavolta et al. (1997).

At grain maturity of common bean plants were evaluated on February 10, 2011 with $90 \%$ of the pods showing yellow color, for grain yield and yield components (number of pods per plant, number of grains per pod and 100-grain weight). In the castor crop, on 05 April 2011, the grain yield and components (number of racemes per plant, number of fruits per raceme and 100-grain weight) were measured with $70 \%$ of mature fruits.

Comparison between the intercropping and monoculture systems is made through the AEI, as reported by Vieira (2006):

$$
\mathrm{AEI}=\mathrm{Ci} / \mathrm{Cm}+\mathrm{Bi} / \mathrm{Bm}
$$

Where, $\mathrm{Ci}$ and $\mathrm{Bi}$ represent the productivity of intercropped castor and common bean, and $\mathrm{Cm}$ and $\mathrm{Bm}$ represent the productivity of monoculture of castor and common bean, considering that, if AEI $>1$,advantageous productivity occurs, if $\mathrm{AEI}=1$, advantageous productivity does not occur, and if $\mathrm{AEI}<1$, disadvantageous productivity occurs.

\subsection{Statistical Analysis}

The data from the factorial treatments were subjected to variance analysis, and when they were significant, the qualitative factor averages (sources) were compared by Tukey test at $5 \%$ probability, while the quantitative factor (B rates) was submitted to regression analysis. The interaction between the factorial treatments versus the additional treatments was compared through Dunnett test at $5 \%$ probability. The data on physiological quality were transformed $(\arcsin \sqrt{\mathrm{x} / 100})$ and submitted to variance analysis. Statistical calculations were performed with the statistical analysis software SISVAR version 5.1 (Ferreira, 2011).

\section{Results and Discussion}

\subsection{Nutritional Aspects of Crops}

The contents of sulfur and boron in common bean plants intercropped with castor and monoculture were significantly affected by the boron source. The other nutrients in the bean plant leaves did not suffer any effect of boron sources tested in intercropping. The leaf nitrogen calcium, magnesium, sulfur, iron and manganese in castor were affected by the boron sources and rates, just as the leaf content of iron and manganese was affected by the factorial $\mathrm{x}$ additional treatment interaction.

The use of boric acid source was more effective in increasing the sulfur content $\left(0.20 \mathrm{dag} \mathrm{kg}^{-1}\right)$, compared with borax $\left(0.10 \mathrm{dag} \mathrm{kg}^{-1}\right)$, in leaves of common bean intercropped with castor (Figure 1). A similar result was observed in leaf boron content in response to the application of the treatments. These results are explained by the occurrence of positive interaction between boron and sulfur caused by the mobility of these nutrients in the plant (Malavolta et al., 1997). Moreover, the fact that boric acid is highly soluble in water and exists in soil in molecular form, not ionic, enables its in-depth movement and allows greater contact with the plant root system 
(Dechen \& Nachtigall, 2006), increasing its availability, associated with greater availability of boron in the boric acid source in relation to borax.

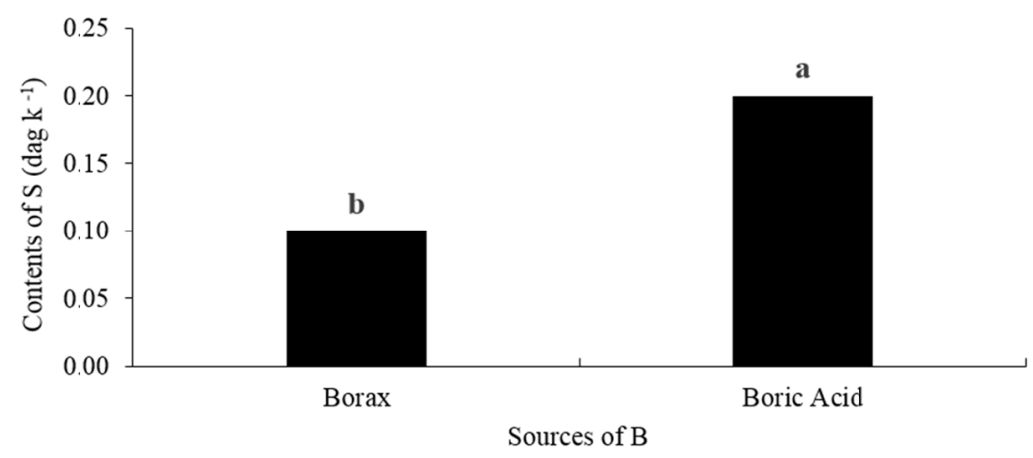

Figure 1. Leaf contents of S the common bean intercropped with castor under different sources of boron. Significant at $5 \%$ probability by $\mathrm{F}$ test

Regarding the leaf nutrient contents in castor crop, it was noted that the nitrogen content was higher with the application of boric acid compared with borax (Figure 2). These differences can certainly beat tributed to the increased availability of these two nutrients within the plant (Malavolta et al., 1997), a similar behavior to that of sulfur in common bean plants. In contrast, the use of borax source produced higher leaf content of calcium (Figure 3), magnesium (Figure 4), sulfur (Figure 5) and manganese (Figure 6) in castor leaves, whereas the iron content in castor leaves was affected by both the sources and levels of boron, showing significant interaction of these factors, with opposite behavior of quadratic curves for the boron sources studied (Figure 7).

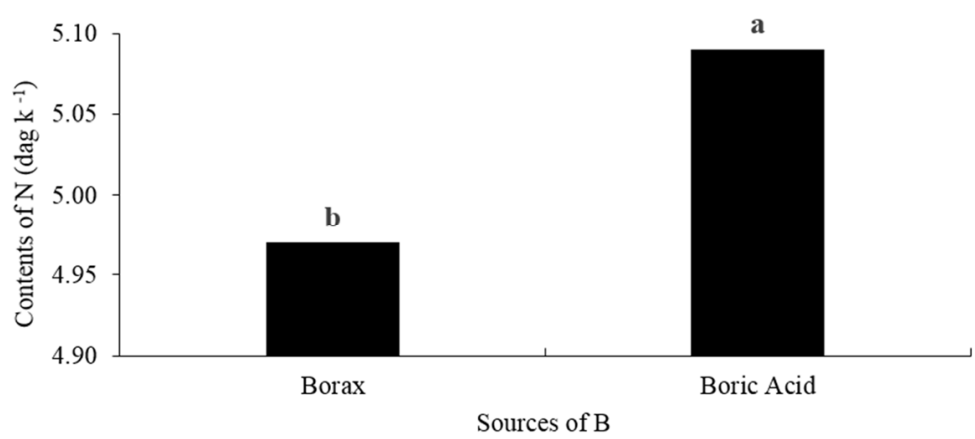

Figure 2. Leaf contents of $\mathrm{N}$ the common bean intercropped with castor under different sources of boron.

Significant at $5 \%$ probability by $\mathrm{F}$ test

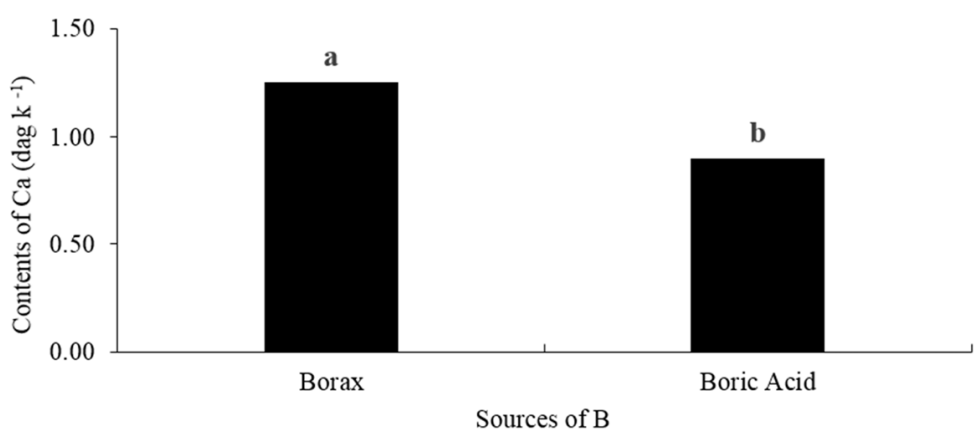

Figure 3. Leaf contents of $\mathrm{Ca}$ the castor intercropped with common bean under different sources of boron. Significant at $5 \%$ probability by $\mathrm{F}$ test 


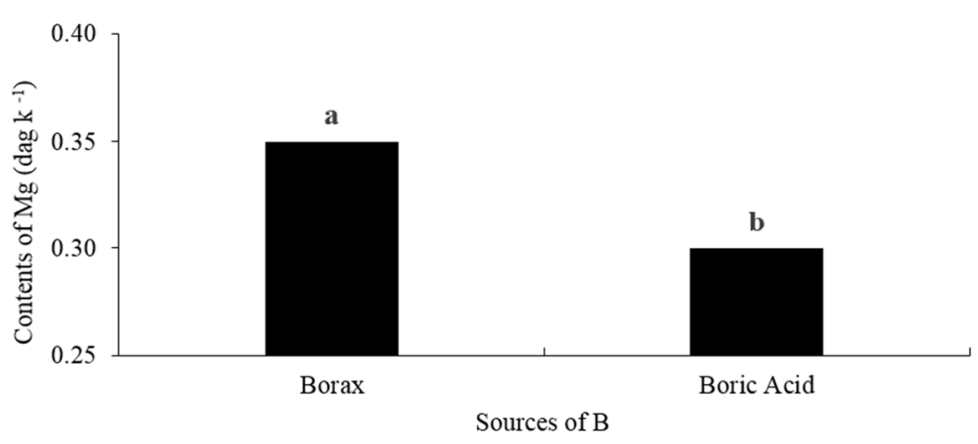

Figure 4. Leaf contents of $\mathrm{Mg}$ the castor intercropped with common bean under different sources of boron. Significant at $5 \%$ probability by $\mathrm{F}$ test

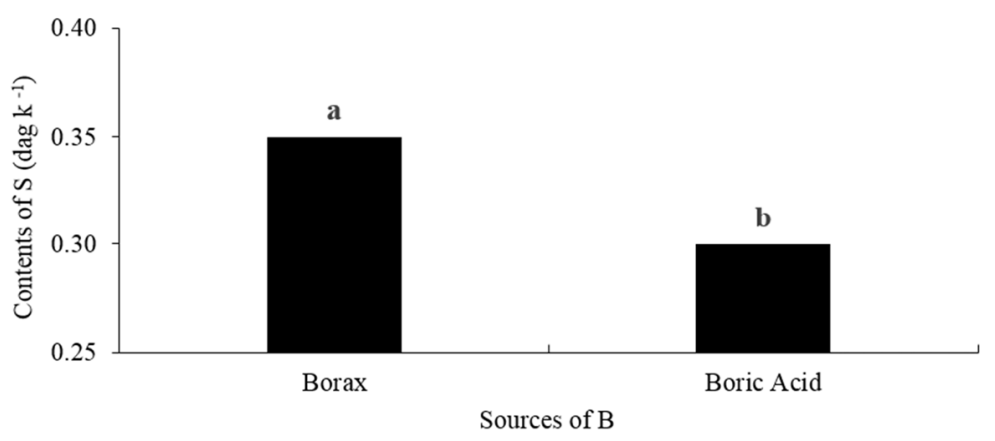

Figure 5. Leaf contents of S the castor intercropped with common bean under different sources of boron. Significant at $5 \%$ probability by $\mathrm{F}$ test

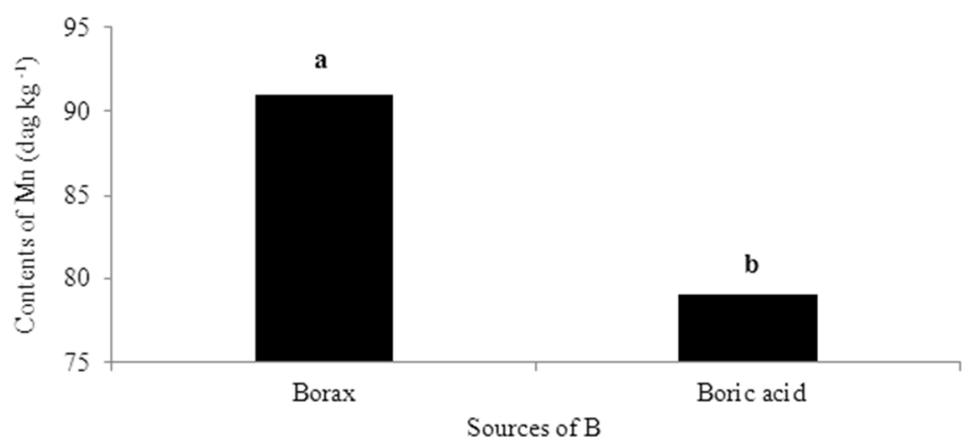

Figure 6. Leaf contents of $\mathrm{Mn}$ the castor intercropped with common bean under different sources of boron. Significant at $5 \%$ probability by $\mathrm{F}$ test 


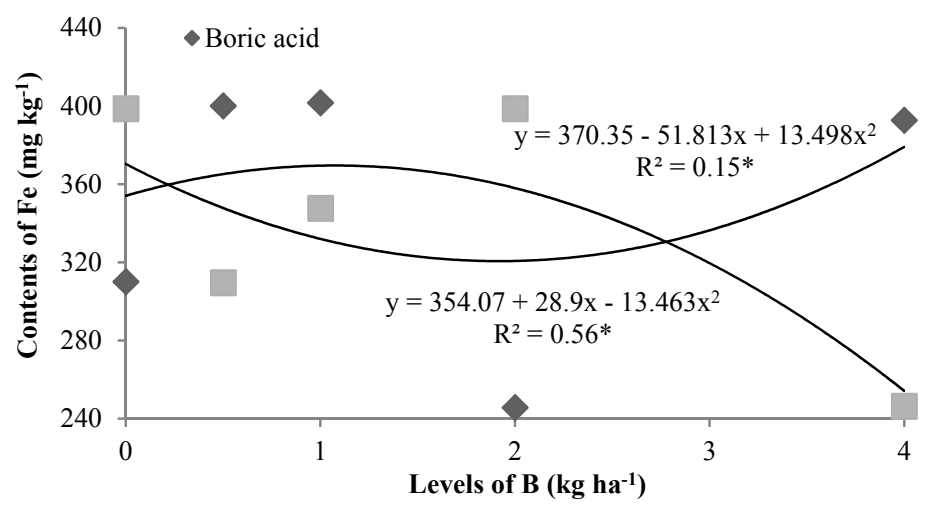

Figure 7. Leaf contents of Fe the castor intercropped with common bean under different levels of boron.

Significant at $5 \%$ probability by $\mathrm{F}$ test

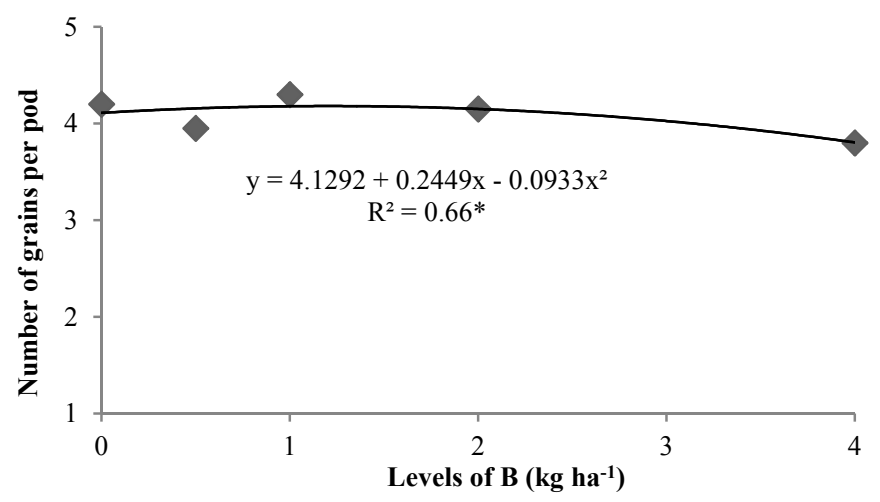

Figure 8. Number of grains per pod the common bean intercropped with castor under different levels of boron. Significant at $5 \%$ probability by $\mathrm{F}$ test

Nutrients such as calcium and manganese are characterized by low and moderate mobility within the plant, respectively (Malavolta et al., 1997), which requires continuous supply of these nutrients during the crop cycle. The increase in leaf calcium and manganese contents promoted by boron application in the form of borax was probably due to slower boron release by that source. However, due to its continuous supply, it also promoted greater mobility of boron, calcium and manganese within the plants. In the case of boric acid, the faster releasing of boron into the soil, with a consequent loss of nutrients caused by processes such as leaching and/or percolation, helps to decrease the amount of boron to plants, hindering the mobility of calcium and manganese within the plant. It should be noted that boron positively influences the absorption and translocation of cations (Dechen \& Nachtigall, 2006), being the likely explanation for the increases in leaf calcium, magnesium and manganese contents in castor in response to the application of boron rates. Conversely, boron deficient plants have poor transportation of cationic nutrients to the plant tissues (Marschner, 1995).

Under the monoculture system, only the leaf boron content was affected by the levels applied with boric acid; the other leaf nutrients were not affected by the treatments. When comparing intercropped and monoculture castor and common bean crop systems, there was virtually no effect of the treatments on leaf nutrient contents analyzed. In castor crop, boron sources affected leaf boron, iron and manganese contents (Figure 3), higher averages being obtained in intercropping than in monoculture. A likely explanation for this behavior is the creation of a favorable microclimate in the intercropping system, such as better soil aeration and moisture, which contributes to greater releasing of boron into the soil through organic matter mineralization, and also favors the predominance of solution-based forms $\left(\mathrm{Fe}^{2+}\right.$ and/or $\left.\mathrm{Mn}^{2+}\right)$ available to plants through oxireduction and quickly soluble in soil (Camargo et al., 2001). It is noteworthy that boron, iron and manganese supply depends much more on factors such as organic matter, moisture, aeration of the medium and soil $\mathrm{pH}$ than the actual amount present in the soil, as reported by Borkert et al. (2001). 
The average macronutrient contents (in dag $\mathrm{kg}^{-1}$ ) of $\mathrm{N}, \mathrm{P}, \mathrm{K}, \mathrm{Ca}, \mathrm{Mg}$ and $\mathrm{S}$ in intercropped common bean leaves were $4.4,0.3,1.7,2.0,0.6$ and 0.1 , respectively; the contents (in $\mathrm{mg} \mathrm{kg}^{-1}$ ) of $\mathrm{B}, \mathrm{Cu}, \mathrm{Fe}, \mathrm{Mn}$ and $\mathrm{Zn}$ micronutrients were 43, 34, 293, 82 and 36. In turn, the average levels of $\mathrm{N}, \mathrm{P}, \mathrm{K}, \mathrm{Ca}, \mathrm{Mg}, \mathrm{S}, \mathrm{B}, \mathrm{Cu}, \mathrm{Fe}, \mathrm{Mn}$ and $\mathrm{Zn}$ found in castor intercropped with common beans were 5.0, 0.5, 2.4, 1.1, 0.4, 0.3, 29, 34, 347, 85 and 38, respectively. For Martinez et al. (1999), the adequate nutrient levels found in common bean leaves in full blooming are macronutrients (in dag $\mathrm{kg}^{-1}$ ): $\mathrm{C}=3.0-3.5 ; \mathrm{P}=0.4-0.7 ; \mathrm{K}=2.7-3.5 ; \mathrm{Ca}=2.5-3.5 ; \mathrm{Mg}=0.3-0.6 ; \mathrm{S}=$ 0.15-0.20, and for castor leaves: $\mathrm{C}=4.0-5.0 ; \mathrm{P}=0.3-0.4 ; \mathrm{K}=3-4 ; \mathrm{Ca}=1.5-2.5 ; \mathrm{Mg}=\mathrm{S}=0.3-0.4$ and 0.3-0.4. The micronutrients (in $\mathrm{mg} \mathrm{kg}^{-1}$ ) in common bean leaves are: $\mathrm{B}=100-150 ; \mathrm{Cu}=8-10 ; \mathrm{Fe}=300-500 ; \mathrm{Mn}$ and $\mathrm{Zn}=200-300=45-55$, whereas for castor leaves, no reference values were found in the literature. Thus, based on reference information, it is noted that, except for boron and manganese (which are below the above-mentioned figures), the average leaf levels of the other nutrients analyzed are in general within or near the limits considered adequate for good growth/development of castor and common bean crops. It should be noted that, although boron and manganese levels are lower than literature values, no symptoms of deficiency of these nutrients were observed in the bean plants.

The boron content in common and castor leaves in the two cropping systems was affected by the treatments, especially with the higher levels tested, which confirms other research results that found increased boron leaf contents in response to the application of increasing levels of borated fertilizers to common bean (Mariano et al., 1999; Souza et al., 2011) and castor (Lange et al., 2005). However, no boron deficiency/toxicity symptoms were found in either culture, under the two systems investigated, in response to the treatment application. This behavior was probably observed because the two crops involved in the research controlled the boron absorption rate, providing good nutrition to the plants, as indicated by the average levels found within the proper limits to those crops. Likewise, the boron available in the soil $(0.5 \mathrm{mg} \mathrm{dm}$, as shown by the analysis results) may have contributed to supplying the needs of the crops involved, especially in the case of the control treatment, which was not provided with boron via fertilization.

\subsection{Agronomic Aspects of Crops}

Among the agronomic aspects evaluated in common bean intercropped with castor, only the number of grains per pod was affected by the boron rates. In the monoculture of castor crop, the average 100-grain weight and the yield were affected by the boron rates, whereas the number of racemes per plant and the number of fruits per raceme were affected by the interaction between intercropping and monoculture (additional treatment). The other characteristics of both crops did not suffer any influence of the tested treatments.

The coefficients of variation of common bean characteristics like number of pods per plant and grain yield were higher than $20 \%$, just like the castor fruit number per raceme and yield. Despite being a genotypic characteristic, as noted, the number of grains per pod suffered quadratic effect from the boron levels (Figure 8), decreasing in value after the $1.31 \mathrm{~kg} \mathrm{ha}^{-1} \mathrm{~B}$ rate, certainly promoted by boron toxicity, since it has the thinnest boundary between deficiency and toxicity among mineral nutrients essential to plants (Malavolta et al., 1997). However, the increase obtained in the number of grains per pod a result of borated fertilization up to the $1.31 \mathrm{~kg} \mathrm{ha}^{-1} \mathrm{~B}$ rate was not reflected in bean productivity growth. This result is inconsistent with other studies (Mascarenhas et al., 1998; Mariano et al., 1999; Souza et al., 2011), which found a positive response by bean plants to borated fertilization, certainly due to the supply of the plant nutritional needs for boron directly from the soil.

The average 100-grain weight of castor intercropped with common bean was affected by the boron rates, decreasing linearly in response to the applications (Figure 9). As previously explained for beans, even though it is a genotypic characteristic, being therefore subject to little influence from environmental conditions, the grain constitution was significantly affected by borated fertilization. Still, unlike the common bean plant, the castor yield was affected by the boron rates, in which the maximum value of $2,040 \mathrm{~kg} \mathrm{ha}^{-1}$ was obtained with the application of $1.9 \mathrm{~kg} \mathrm{ha}^{-1}$ of boron (Figure 10). These results confirm the above-raised hypothesis about the harmful effects of borated fertilization when used in dosage higher than recommended.

The average yield produced by castor intercropped with common bean $\left(1,500 \mathrm{~kg} \mathrm{ha}^{-1}\right)$ was approximately two and a half times the national average obtained with monoculture of castor- $573 \mathrm{~kg} \mathrm{ha}^{-1}$ in the $2014 / 15$ harvest (CONAB, 2016) - meaning that the secondary culture did not hamper the production of castor. It should be noted that, as reported by Vieira (2006), the common bean crop is considered as an extra product of the activity, which brings additional financial gains to producers. 


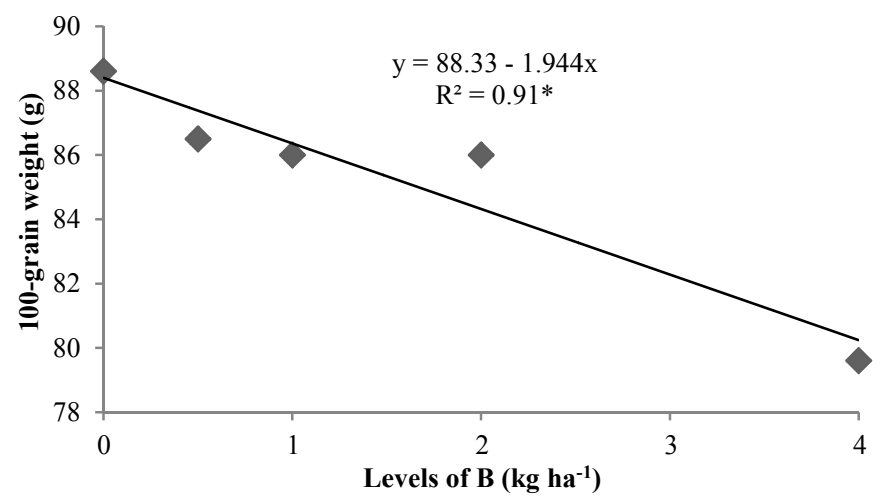

Figure 9. 100-grain weight of castor intercropped with common bean under different levels of boron. Significant at $5 \%$ probability by $\mathrm{F}$ test

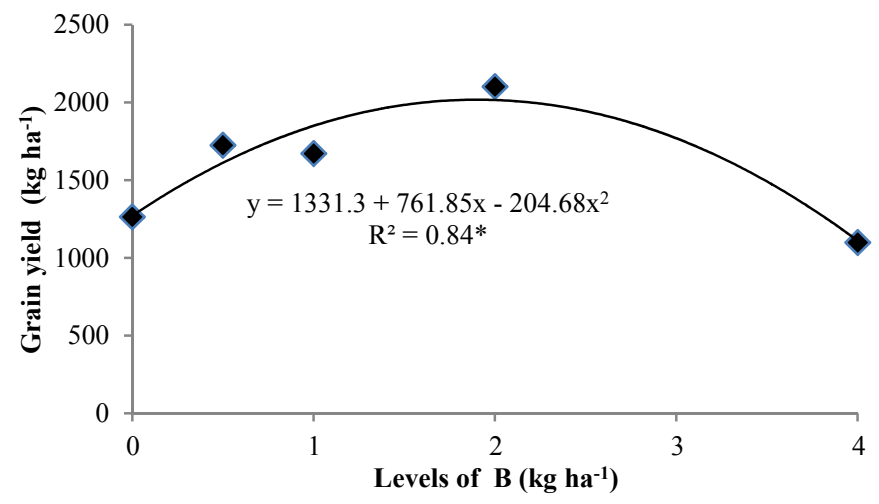

Figure 10. Grain yield of castor intercropped with common bean under different levels of boron. Significant at $5 \%$ probability by $\mathrm{F}$ test

When comparing the additional treatment (monoculture) with intercropping, significant difference is observed in the number of racemes per plant (Figure 11) and number of fruits per raceme (Figure 12) in castor. Intercropping provided an average number of racemes per plant of 14, lower than monoculture, 33. Conversely, the number of fruits per raceme in intercropping, 34 on average, was higher than in monoculture, with an average of 21 (Figure 5). In a study carried out by Carvalho (2005), in a BRS Paraguaçu cultivar, an average of 30 fruits per raceme was found, a value close to those obtained in this research.

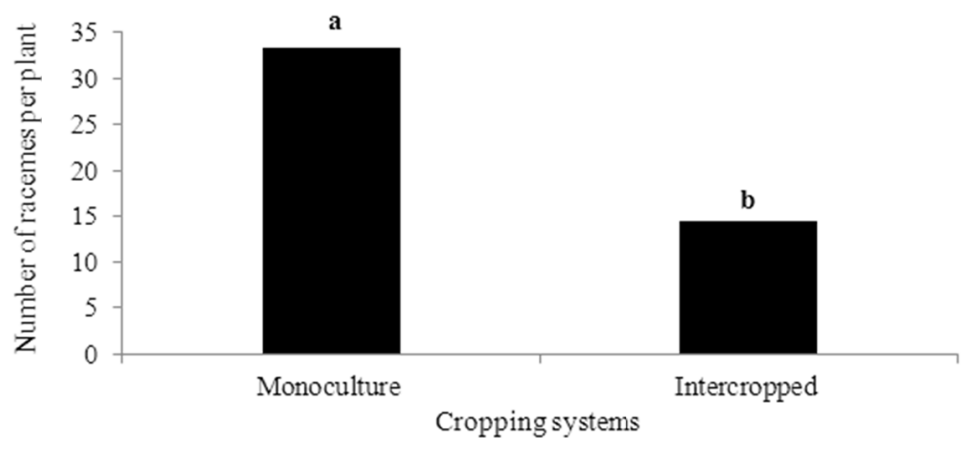

Figure 11. Number of racemes per plant of castor intercropped with common bean under different cropping systems. Significant at $5 \%$ probability by $\mathrm{F}$ test 


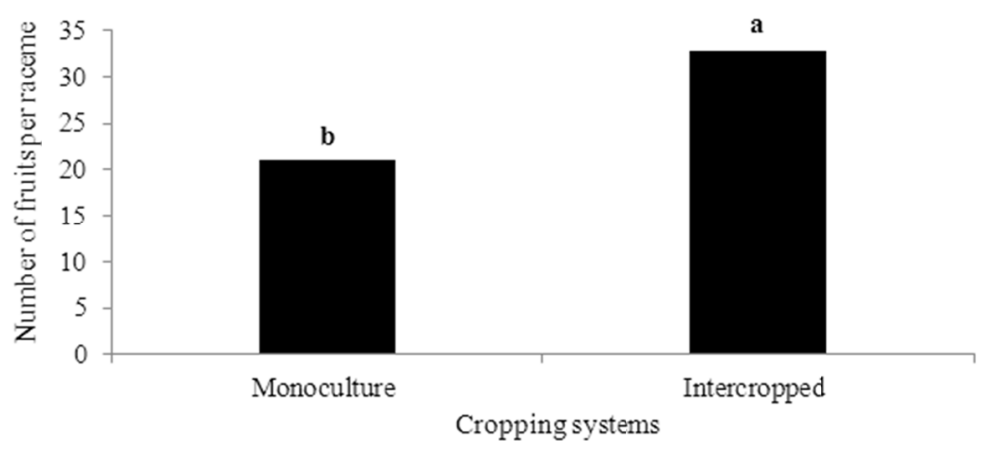

Figure 12. Number of fruits per raceme of castor intercropped with common bean under different cropping systems. Significant at $5 \%$ probability by $\mathrm{F}$ test

According to the AEI results obtained with the boron sources applied (Table 1), the intercropping system can again be considered more efficient than monoculture, as the values ranged from 1.86 to 1.91, that is, above 1.0. The biological evaluation of the cropping systems was studied through the AEI, which showed advantageous productivity of castor and common bean intercropping over monoculture with all the boron levels applied, values ranging from 1.73 to 2.07 (Table 2). The average AEI value obtained with the boron levels was 1.88, which allows stating that the intercropping system is $88 \%$ more efficient than monoculture. Moreover, a 1.88 AEI value implies the need for incorporation of an additional 0.9-hectare monoculture area of the studied species, compared to intercropping, in order to obtain the same yield.

Table 1. I/M ratio (intercrop yield/monoculture yield) and Area Equivalence Index (AEI) of intercropped common bean (Phaseolus vulgaris L.) and castor (Ricinus communis L.)

\begin{tabular}{llll}
\hline Sources & I/M Common bean & I/M Castor & AEI \\
\hline Boric acid & $1.01^{*}$ & $0.90^{* *}$ & $1.91^{* * *}$ \\
Borax & 0.93 & 0.93 & 1.86 \\
\hline
\end{tabular}

Note. Production $\left(\mathrm{kg} \mathrm{ha}^{-1}\right)$ of monoculture of common bean under different boron sources: Boric acid $=430.71$ $\mathrm{kg} \mathrm{ha}^{-1} \mathrm{~B}$; Borax $=406.50 \mathrm{~kg} \mathrm{ha}^{-1} \mathrm{~B}$. Production $\left(\mathrm{kg} \mathrm{ha}^{-1}\right)$ of intercropped common bean under different boron sources: Boric acid $=428.95 \mathrm{~kg} \mathrm{ha}^{-1} \mathrm{~B}$; Borax $=437.43 \mathrm{~kg} \mathrm{ha}{ }^{-1}$ B. Example of AEI calculation: * $(430.71 / 428.95) ; * *(1,506.73 / 1,665) ; * * * \mathrm{I} / \mathrm{M}$ Common bean + I/M Castor.

Table 2. I/M ratio (intercrop yield/monoculture yield) and Area Equivalence Index (AEI) of intercropped common bean (Phaseolus vulgaris L.) and castor (Ricinus communis L.)

\begin{tabular}{llll}
\hline Levels $\left(\mathrm{kg} \mathrm{ha}^{-1}\right)$ & I/M Common bean & I/M Castor & AEI \\
\hline 0 & $0.92^{*}$ & $0.88^{* *}$ & $1.80^{* * *}$ \\
0.5 & 0.86 & 0.87 & 1.73 \\
1 & 0.96 & 0.97 & 1.93 \\
2 & 1.11 & 0.96 & 2.07 \\
4 & 0.99 & 0.89 & 1.88 \\
\hline
\end{tabular}

Note. Production $\left(\mathrm{kg} \mathrm{ha}^{-1}\right)$ of monoculture of common bean under different boron rates: $0\left(\mathrm{~kg} \mathrm{ha}^{-1} \mathrm{~B}\right)=437.64$; $0.5\left(\mathrm{~kg} \mathrm{ha}^{-1} \mathrm{~B}\right)=462.18 ; 1\left(\mathrm{~kg} \mathrm{ha}^{-1} \mathrm{~B}\right)=454.31 ; 2\left(\mathrm{~kg} \mathrm{ha}^{-1} \mathrm{~B}\right)=402.56 ; 4\left(\mathrm{~kg} \mathrm{ha}^{-1} \mathrm{~B}\right)=409.25$. Production $(\mathrm{kg}$ $\left.\mathrm{ha}^{-1}\right)$ of intercropped common bean under different boron rates: $0\left(\mathrm{~kg} \mathrm{ha}^{-1} \mathrm{~B}\right)=401.25 ; 0.5\left(\mathrm{~kg} \mathrm{ha}^{-1} \mathrm{~B}\right)=398.06$; $1\left(\mathrm{~kg} \mathrm{ha}^{-1} \mathrm{~B}\right)=438.12 ; 2\left(\mathrm{~kg} \mathrm{ha}^{-1} \mathrm{~B}\right)=447.46 ; 4\left(\mathrm{~kg} \mathrm{ha}^{-1} \mathrm{~B}\right)=408.15$. Example of AEI calculation: * (401.25/437.64); ** (1,263.5/1,438); *** I/M common bean + I/M castor.

The results for AEI obtained herein are consistent with other research studies where intercropping castor with other species proved more efficient than monoculture (Corrêa et al., 2006; Azevedo et al., 2007; Kumar et al., 2010; Beltrão et al., 2010a, 2010b; Pinto et al., 2011; Teixeira et al., 2011, 2012; Pereira et al., 2015; Dutra et al., 2017; Lisboa et al., 2018). 


\section{Conclusions}

The leaf nutrient contents in common and castor monocultures are not affected, either by borated fertilization or by the intercropping versus monoculture interaction.

The yield of common bean intercropped with castor is not affected, either by borated fertilization or by the intercropping versus monoculture interaction. In contrast, the highest yield of castor intercropped with common bean is achieved with the $1.9 \mathrm{~kg} \mathrm{ha}^{-1}$ boron of level, regardless of the source used.

The yield of castor is not affected significantly by the intercropping versus monoculture interaction. The different boron level applied, the common and castor intercropping system is more efficient than monoculture.

\section{References}

Alvarez, J. W. R., Fois, D. A. F., Riego, N. G. G., Olhagaray, J. F. I., \& Paredes, G. A. R. (2015). Tártago asociado a cultivos anuales: una opción para la agricultura familiar. Investigación Agraria, 17, 27-35. https://doi.org/10.18004/investig.agrar.2015.junio.27-35

Azevedo, D. M. P., Beltrão, N. E. M., Severino, L. S., Santos, J. W., \& Leão, A. B. (2007). Arranjos de fileiras no consórcio mamoneira com milho no semi-árido paraibano. Revista Brasileira de Oleaginosas e Fibrosas, 11, 91-105.

Beltrão, N. E. M., Vale, L. S., Marques, L. F., Cardoso, G. D., \& Maracaja, P. B. (2010a). Época relativa de plantio no consórcio mamona e gergelim. Revista Verde de Agricultura e Desenvolvimento Sustentável Grupo Verde de Agricultura Alternativa, 5, 67-73.

Beltrão, N. E. M., Vale, L. S., Marques, L. F., Cardoso, G. D., \& Outo, J. S. (2010b). Consórcio mamona e amendoim: opção para a agricultura familiar. Revista Verde de Agricultura e Desenvolvimento Sustentável Grupo Verde de Agricultura Alternativa, 5, 222-227.

Borkert, C. M., Pavan, M. A., \& Bataglia, O. C. (2001). Disponibilidade e avaliação de elementos catiônicos: ferro e manganês. In M. E. Ferreira, M. C. P. Cruz, B. V. Raij, \& C. A. Abreu (Eds.),Micronutrientes e elementos tóxicos na agricultura (pp. 151-185). Jaboticabal: CNPq/FAPESP/POTAFOS.

Camargo, O. A., Alleoni, L. R. F., \& Casagrande, J. C. (2001). Reações dos micronutrientes e elementos tóxicos no solo. In M. E. Ferreira, M. C. P. Cruz, B. V. Raij, \& C. A. Abreu (Eds.), Micronutrientes e elementos tóxicos na agricultura (pp. 89-119). Jaboticabal, CNPq/FAPESP/POTAFOS.

Carvalho, B. L. C. (2005). Manual do cultivo da mamona. Salvador: EBDA.

CONAB (Companhia Nacional de Abastecimento). (2016). Acompanhamento da safra de grãos 2015/16 (V. 16). Retrieved from http://www.conab.gov.br/OlalaCMS/uploads/arquivos/16_07_29_15_12_51_boletim_graos julho_2016.pdf

Corrêa, M. L. P., Távora, F. J. A. F., \& Pitombeira, J. B. (2006). Comportamento de cultivares de mamona em sistemas de cultivo isolados e consorciados com caupi e sorgo granífero. Revista Ciência Agronômica, 37, 200-207.

Dechen, A. R., \& Nachtigall, G. R. (2006). Micronutrientes. In M. S. Fernandes (Ed.), Nutrição mineral de plantas (pp. 327-354). Viçosa, MG: Sociedade Brasileira de Ciência do Solo.

Devide, A. C. P., Castro, C. M., Santos, R. D. F., \& Anacleto, A. H. (2010). Plantio direto de mamona 'IAC 80' com culturas alimentares. Ciência e Agrotecnologia, 34, 653-659. https://doi.org/10.1590/S1413-7054201 0000300018

Diniz Neto, M. A., Silva, I. F., Diniz, B. L. M. T., Pereira, A. A., \& Pereira, A. R. (2012). Componentes de produção de mamona em função de níveis de adubação nitrogenada e desfolha. Revista Ciência Agronômica, 43, 546-553. https://doi.org/10.1590/S1806-66902012000300018

Dutra, W. F., Melo, A. S., Dutra, A. F., Brito, M. E. B., Filgueiras, L. M. B., \& Meneses, C. H. S. G. (2017). Eficiência fotossintética, trocas gasosas e produção da mamoneira consorciada com amendoinzeiro no semiárido brasileiro. Revista Brasileira Engenharia Agrícola e Ambiental, 21, 106-110. https://doi.org/ 10.1590/1807-1929/agriambi.v21n2p106-110

Embrapa (Empresa Brasileira de Pesquisa Agropecuária). (2004). Cultivar Pérola. Embrapa/Centro Nacional de Pesquisa de Arroz e Feijão. Retrieved from http://www.embrapa.br/imprensa/noticias 
Embrapa (Empresa Brasileira de Pesquisa Agropecuária). (2007). Cultivares: Cultivar Paraguaçu. Embrapa/Centro Nacional de Pesquisa de Algodão. Retrieved from http://www.cnpa.embrapa.br/produtos/ mamona/cultivares.html

Ferreira, R. F., Teixeira, I. R., Reis, E. F., Silva, A. G., \& Silva, G. C. (2014). Management of top-dressed nitrogen fertilization in the common bean/castor intercropping system. Australian Journal of Crop Science, 8, 1086-1092.

Furtado, G. F., Souza, A. S., Lacerda, R. R. A., Chaves, L. H. G., Sousa Júnior, J. R., \& Sousa, J. R. M. (2017). Produção de feijão-caupi e gergelim consorciado com mamoneira no Semiárido paraibano. Revista Verde de Agroecologia e Desenvolvimento Sustentável, 12, 1-6. https://doi.org/10.18378/rvads.v12i1.4890

Kumar, H. C. S., Mudalagiriyappa, J. L., Nanjappa, H. V., \& Ramachandrappa, B. K. (2010). Productive performance of castor (Ricinus communis L.) based intercropping systems under rainfed conditions of Central Dry Zone in Karnataka. Journal of Agricultural Sciences, 44, 481-484.

Lange, A., Martines, A. M., Silva, M. A. C., Sorreano, M. C. M., Cabral, C. P., \& Malavolta, E. (2005). Efeito de deficiência de micronutrientes no estado nutricional da mamoneira cultivar Íris. Pesquisa Agropecuária Brasileira, 40, 61-67. https://doi.org/10.1590/S0100-204X2005000100009

Lima, R. L. S., Severino, L. S., Albuquerque, R. C., Beltrão, N. E. M., \& Sampaio, L. R. (2008). Casca e torta de mamona avaliados em vasos com fertilizantes orgânicos. Revista Caatinga, 21, 102-106.

Lisboa, C. F., Silva, D. D. A., Teixeira, I. R., Silva, A. G., \& Mota, J. H. (2018). Agronomic characteristics of common bean and castor bean hybrids in intercropping and monocropping. Revista Brasileira de Engenharia Agrícola e Ambiental, 22, 200-205. https://doi.org/10.1590/1807-1929/agriambi.v22n3 p200-205

Lithourgidis, A. S., Dordas, C. A., Damalas, C. A., \& Vlachostergios, D. N. (2011). Annual intercrops: An alternative pathway for sustainable agriculture. Austtralian Journal of Crop Science, 5, 396-410.

Malavolta, E., Vitti, G. C., \& Oliveira, S. A. (1997). Avaliação do estado nutricional das plantas: Princípios e aplicações (2nd ed.). Piracicaba: Potafós.

Mariano, E. D., Faquin, V., Furtini Neto, A. E., Mariano, I. O. S., \& Oliveira Jr., A. C. (1999). Boro em solos de várzea do sul de Minas Geraise a cultura do feijoeiro. Scientia Agricola, 56, 1051-1058. https://doi.org/ 10.1590/S0103-90161999000500006

Marschner, H. (1995). Mineral nutrition of higher plants. San Diego: Academic Press.

Martinez, H. E. P., Carvalho, J. G., \& Souza, R. B. (1999). Diagnose foliar. In A. C. Ribeiro, P. T. G. Guimarães, \& V. V. H.Alvarez (Eds.), Recomendação para o uso de corretivos e fertilizantes em Minas Gerais (pp. 143-168). Viçosa: Comissão de Fertilidade do Estado de Minas Gerais.

Mascarenhas, H. A. A., Tanaka, R. T., Nogueira, S. S. S., Carmello, Q. A. C., \& Ambrosano, E. J. (1998). Resposta do feijoeiro a doses de boro em cultivo de inverno e de primavera. Bragantia, 57, $153-158$. https://doi.org/10.1590/S0006-87051998000200020

Moro, E., Crusciol, C. A. C., \& Carvalho, L. L. T. (2011). Épocas de aplicação de nitrogênio para híbridos de mamona no sistema plantio direto em safrinha. Semina: Ciências Agrárias, 32, 391-410. https://doi.org/ 10.5433/1679-0359.2011v32n2p391

Oliveira Filho, A. F., Bezerra, F. T. C., Pitombeira, J. B., Dutra, A. S., \& Barros, G. L. (2016). Eficiência agronômica e biológica nos consórcios da mamoneira com feijão-caupi ou milho. Revista Ciência Agronômica, 47, 729-736. https://doi.org/10.5935/1806-6690.20160087

Oliveira, J. P. M., Scivittaro, W. B. Castilhos, R. M. V., \& Oliveira Filho, L. C. I. (2010). Adubação fosfatada para cultivares de mamoneira no Rio Grande do Sul. Ciência Rural, 40, 1835-1839. https://doi.org/ 10.1590/S0103-84782010000800027

Oliveira, R. L., Muniz, J. A., Andrade, M. J. B., \& Reis, R. L. (2009). Precisão experimental em ensaios com a cultura do feijão. Ciência e Agrotecnologia, 33, 113-119. https://doi.org/10.1590/S1413-70542009000 100016

Pereira, F. S., Teixeira, I. R., Pelá, A., Reis, E. F., Silva, G. C., Timossi, P. C., \& Silva, A. G. (2015). Agronomic performance of kidney bean and castor bean cultivars in intercropping and monocropping systems under weed competition. Australian Journal of Crop Science, 9, 614-620. 
Pimentel Gomes, F. (1990). Curso de estatística experimental (13th ed.). São Paulo: Nobel.

Pinto, C. M., Filho, F. A. S., Cysne, J. R. B., \& Pitombeira, J. B. (2011). Produtividade e índices competição da mamona consorciada com gergelim, algodão, milho e feijão. Revista Verde de Agricultura e Desenvolvimento Sustentável Grupo Verde de Agricultura Alternativa, 6, 75-85.

Seplan (Secretária de Planejamento do Estado de Goiás). (2012). Coordenadas geográficas dos municípios. Retrieved from http://portalsepin.seplan.go.gov.br

Silva, T. R. B., Leite, V. E., Silva, A. R. B., \& Viana, L. H. (2007). Adubação nitrogenada em cobertura na cultura da mamona em plantio direto. Pesquisa Agropecuária Brasileira, 42, 1357-1359. https://doi.org/ $10.1590 / \mathrm{S} 0100-204 \mathrm{X} 2007000900018$

Souza, H. A. S., Natale, W., Rozane, D. E., Hernandes, A., \& Romualdo, L. M. (2011). Calagem e adubação boratada na produção de feijoeiro. Revista Ciência Agronômica, 42, 249-257. https://doi.org/10.1590/ S1806-66902011000200001

Teixeira, I. R., Mota, J. H., \& Silva, A. G. (2005). Consórcio de hortaliça. Semina. Ciências Agrárias, 24, 507-514.

Teixeira, I. R., Silva, G. C., Oliveira, J. A. P., \& Timossi, P. C. (2012). Arranjos de plantas do feijoeiro-comum consorciado com mamona. Revista Caatinga, 25, 85-91. https://doi.org/10.5433/1679-0359.2005v26n4p507

Teixeira, I. R., Teixeira, G. C. S., Timossi, P. C., \& Silva, A. G. (2011). Desempenho agronômico de cultivares de feijão-comum consorciado com mamona. Revista Caatinga, 24, 55-61.

Vieira, C. (2006). Cultivos consorciados. In C. Vieira, T. J. Paula Júnior, \& A. Borém (Eds.), Feijão (2nd ed., pp. 493-528).

\section{Abbreviations}

AEI: Area Equivalence Index; DAE: days after emergence.

\section{Copyrights}

Copyright for this article is retained by the author(s), with first publication rights granted to the journal.

This is an open-access article distributed under the terms and conditions of the Creative Commons Attribution license (http://creativecommons.org/licenses/by/4.0/). 